\title{
Matrices de inclusión para obtención de cortes de tejidos en vibrátomo en estudios citoquímicos
}

\author{
Miriam Velandia ', Zayra Garavito ', María Leonor Caldas ${ }^{2}$, Hernán Hurtado'
}

\begin{abstract}
Resumen
Para estudios citoquímicos en diferentes muestras de tejidos, de tamaños pequeños, se hace necesaria la utilización de una matriz inerte que genere soporte y estabilidad al tejido en el momento de obtener cortes de $50 \mu \mathrm{m}$ en vibrátomo. Por esta razón se ensayaron cinco matrices: agar granulado, agar purificado, agar-agar, agarosa y gelatina, a diferentes concentraciones. Tanto con el agar-agar como con la agarosa se obtuvieron los mejores resultados, puesto que estos ofrecen mayor estabilidad al tejido, fluyen fácilmente al servirse y su textura es muy homogénea, requisitos necesarios para la obtención de cortes precisos, utilizables en citoquímica, inmunocitoquímica y trazados histoquímicos.
\end{abstract}

\section{Embedding matrixes for obtaining vibratome tissue slices for cytochemistry studies}

\section{Summary}

The use of an inert supporting matrix is necessary in order to obtain $50 \mu \mathrm{m}$ vibratome tissue slices for cytochemistry studies when using small tissue samples.

Five matrices were assayed: granulate agar, purified agar, agar-agar, agarose and gelatine at different concentrations.

The best results were obtained with agar-agar and agarose which both gave good tissue stability, providing an easy handling of samples and resulting in more homogeneous texture. These requirements are important if good slices are to be obtained which will be useful for cytochemistry, immunocytochemistry and histochemical tracing studies.

Para mayor eficiencia de los estudios citoquímicos en tejidos, se recomienda que los cortes no superen los 50 a $150 \mathrm{~mm}$ de grosor, los cuales permiten un mejor acceso de los componentes del medio de activación enzimática; el tiempo de incubación dependerá del grosor de los tejidos, a menor grosor menos tiempo de incubación (1). En muchos casos, se utilizan muestras de tejido de tamaños pequeños, los cuales necesitan de una matriz que genere soporte, estabilidad al tejido bajo un proceso de fijación o sin él (2), y que no reaccione cruzada o inespecificamente con la muestra. Generalmente, se utiliza el vibrátomo y/o el crióstato (instrumento para obtener cortes en congelación de 5 a $10 \mu \mathrm{m}$ ), para obtener estos cortes, sin embargo teniendo

1 Laboratorio de Neurociencias,

2 Unidad de Microscopía y Análisis de Imágenes, Instituto Nacional de Salud, Santafé de Bogotá, Colombia.

Recibido para publicación 24 de noviembre de 1998, aprobado 12 de marzo de 1999 
en cuenta los requerimientos de un estudio citoquímico y ultraestructural, el uso del vibrátomo ofrece ciertas ventajas con respecto al crióstato como lo son : los costos del equipo, sus materiales (medios líquidos de soporte, cuchillas y accesorios), su fácil manejo, incluso se pueden realizar cortes de material sin fijar a diferente temperatura y sin necesidad de alguna matriz de acuerdo con el tamaño de la muestra; también permite la obtención de cortes con un amplio rango de grosor y contribuye a una buena preservación morfológica, hecho fundamental en la interpretación de resultados en estos estudios tanto para microscopía de luz como para microscopía electrónica. El vibrátomo consiste en un instrumento que posee un brazo mecánico que vibra de manera horizontal en el cual se coloca la cuchilla; un porta muestras que se moviliza mecánicamente, de tal modo que la muestra es cortada homogéneamente al paso de la cuchilla sobre esta, alcanzando grosores de los cortes entre 50 y $200 \mu \mathrm{m}$.

Uno de los elementos mas utilizados como matriz, es el agar $(3,4,5)$, un polisacárido extraído de las algas marinas (rodofíceas), sometido a tratamientos de purificación los cuales reducen el contenido de minerales. Otro polisacárido es la agarosa, obtenida del refinamiento del agar, disminuyendo el porcentaje de los minerales hasta una concentración óptima. La gelatina es un compuesto nitrogenado extraído de la piel del cerdo $(6,7)$.

\section{Materiales y métodos}

Ratones ICR, fueron sacrificados en cámara de $\mathrm{CO}_{2}$, los nervios ciáticos fueron removidos y extraídos del animal. Luego se cortaron en 15 fragmentos de aproximadamente 3 a $5 \mathrm{~mm}$ y se fijaron en una solución de paraformaldehido $1 \%$ y glutaraldehido $0,5 \%$ en buffer cacodilato $0,1 \mathrm{M}$ (8) $\mathrm{pH} \mathrm{7,2} \mathrm{por} \mathrm{una} \mathrm{hora;} \mathrm{las} \mathrm{muestras} \mathrm{fueron}$ lavadas en el mismo buffer. La preparación de las matrices se realizó en agua destilada a $100^{\circ} \mathrm{C}$ en la cual se disolvieron los agares; manteniéndolos en agitación constante hasta obtener un aspecto transparente. Las matrices fueron: agar granulado (Becton Dickinson),BBL Agar purificado (Becton Dickinson), BBL agar-agar, MERCK, agarosa, FMC, Gelatina, Sigma de 300 bloom, en las concentraciones de $5 \%, 7 \%$ y $10 \%$. Estas fueron servidas en moldes plásticos y la inclusión de la muestra se realizó a $30^{\circ} \mathrm{C}$. La gelificación se completó a $4^{\circ} \mathrm{C}$, y los cortes se realizaron en vibrátomo Campdem instrumental, con un grosor de $50 \mu \mathrm{m}$ y fueron recogidos en buffer cacodilato $0,1 \mathrm{M}$. Finalmente los cortes se colorearon con azul de toluidina.

\section{Resultados}

Al evaluar la resistencia y compactación de la matriz, también se tuvieron en cuenta aspectos como la viscosidad, textura y estabilidad del tejido en esta y su interacción con el buffer en el baño en que flotaron los cortes en el momento de ser recogidos. Los resultados obtenidos fueron los siguientes:

Con el agar granulado, BBL al $5 \%$ y $7 \%$, se observó que el tejido no tenía estabilidad suficiente, de tal forma que al paso de la cuchilla, el tejido se dobló y se deslizó fuera de la matriz. Así que al cabo de 5 o 6 cortes el tejido se separó de la misma. Los cortes al $10 \%$ de este agar fueron difíciles de realizar, debido que a esta concentración, el agar es muy denso y fluye lentamente, formándose fácilmente burbujas, que le proporcionaron inestabilidad al tejido separándolo de la matriz.

En el agar purificado, BBL al $5 \%$ y $7 \%$, no se obtuvieron cortes porque la textura de esta matriz fue muy grumosa, además la consistencia no fue homogénea, generando en el tejido poco soporte, desprendiéndose de la matriz. Al $10 \%$ no se obtuvieron cortes por que sucedió lo mismo que con el agar granulado a esta concentración, faltaba estabilidad y se separaba el tejido en el momento de obtener el corte.

El agar-agar MERCK en las tres concentraciones probadas ofreció gran estabilidad al tejido, fue muy homogéneo y compacto; el paso de la cuchilla sobre este fue preciso y permitió obtener cortes uniformes. Fue fácil de servir debido a que fluye libremente.

En la agarosa FMC al 5\% el tejido se movió y se separó de la matriz, debido a que esta fué muy frágil. Al $7 \%$ y $10 \%$ la agarosa presentó gran 
compactación al servir, no se formaron burbujas, ofreciendo estabilidad al tejido y la cuchilla se desplazó suavemente, resultando cortes muy homogéneos y precisos.

Con la inclusión del tejido en la gelatina, se observó que la matriz es inestable despegándose del portamuestras. Con las tres concentraciones no se obtuvieron cortes, por presentar inestabilidad desde su manipulación al comienzo de la obtención de los cortes.

\section{Discusión}

Las diferencias entre las matrices ensayadas: agar, agarosa y gelatina, al igual que su modo de preparación son poco notorias; se presentan diferencias en cuanto a su textura y grado de compactación, debido probablemente a los niveles de pureza.

Se observó que el buffer en el que se recogieron los cortes puede afectar la capacidad de compactación y de soporte de las matrices, es decir que existe alguna interacción entre los componentes del agar y el buffer utilizado, generando la inestabilidad que se observó en algunas matrices con el buffer cacodilato. La inestabilidad, también puede ser explicada por las débiles interacciones físicas o mecánicas que se generan permitiendo la formación de espacios entre el tejido y el agar utilizado, haciendo que este se moviera y se desplazara dentro de la matriz, separándose finalmente al cabo del tiempo; esto se observó en el agar granulado BBL al $5 \%$ y $7 \%$ y en la agarosa al $5 \%$.

Según las necesidades del laboratorio en citoquímica e inmunocitoquímica principalmente, el uso del agar como matriz a diferentes concentraciones, es recomendable. En nuestro caso el agar MERCK y la agarosa FMC, presentaron las mejores características de estabilidad, textura, fluidez y homogeneidad en el momento de gelificar. El agar MERCK presenta una ventaja adicional que es su menor costo comparado con la agarosa, con la que se obtuvieron los mismos resultados. Ambos presentaron otras características favorables, como la facilidad para prepararse y servirse. Una característica de gran interés, para los estudios citoquímicos, es la temperatura de gelificación; ya que al sobrepasar los $40^{\circ} \mathrm{C}$, pueden desnaturalizarse algunas proteínas, sin embargo los agares ensayados pueden ser servidos a temperaturas de $30^{\circ} \mathrm{C}$ sin gelificar, evitando así posibles daños a las proteínas en general. Por otra parte ningún agar es tóxico, mantiene las muestras hidratadas y es posible conservarlas dentro del agar a $4^{\circ} \mathrm{C}$ debidamente cubiertas.

La utilización de geles como matriz de inclusión de tejidos se conoce ampliamente, sin embargo en la literatura no se encuentra un estudio que evalúe tipos de matrices, concentración y detalles del procedimiento en general. Por lo anterior, se considera que el aporte de este escrito es importante destacando su aplicación en la inclusión de muestras de tejido, lo cual permite obtener cortes homogéneos y con buena preservación morfológica en estudios inmunohistoquímicos, trazados, histoquímicos y citoquímicos entre otros, tanto en microscopía de luz como en microscopía electrónica.

\section{Agradecimientos}

Los autores expresan sus agradecimientos a la Bióloga. Helga Niño,MSc. Soordinadora del Grupo de Medios de Cultivo, por su colaboración en la preparación de los agares utilizados.

\section{Referencias}

1. Lewis P.R. Metal Precipitation Methods For Hydrolytic Enzymes. In : Glauert A.M. Editor . Staining Methods For Sectioned Material. Practical Methods In Electron Microscopy. Oxford ;1977. P. 137-223.

2. Prophet E.B, Mills B, Arrington J.B and Sobin L.H. Laboratory methods in histochnology. Armed Forces Institute of Pathology. Washington D.C ;1992. P. 25-32.

3. Barry M. Ecto-Calcium-Dependent ATPasa Activity Of Mammalian Taste Bud Cells. J Histochem Cytochem 1992;40:1919-28.

4. Firth J.A. Problems of specificity in the use of a strontium capture technique for the cytochemical localization of ouabain-sensitive. Potassium-dependent phosphatase in mammalian renal tubules. J Histochem Cytochem 1974;22:1163-8.

5. Zhongrong L, Schultz R, Whitter E. Ultrastructural localization of phosphatase activity in the guinea pig pineal 
gland by the cerium technique. J Histochem Cytochem 1990;38:793-801.

6. Power D and McCuen PJ. Manual of BBL Products And Laboratory Procedures. Sixth Edition. Becton Dickinson Microbiology System. U.S.A ; 1988. P. 296-7.
7. Schuchardt T. Reactivos Para Diagnostico. Productos Químicos. MERCK. Alemania ;1987. P. 130.

8. Weakley B. How dangerous is sodium cacodylate ? J Microscopy $1992 ; 109: 249-51$. 